\title{
Supraorbital Vein
}

National Cancer Institute

\section{Source}

National Cancer Institute. Supraorbital Vein. NCI Thesaurus. Code C33707.

A superficial vein that ascends the forehead and joins with the frontal vein to form the angular vein. 